\title{
ANALISIS VARIASI SPASIAL KONSENTRASI SULFAT DI SUNGAI BATANG ARAU, PADANG, SUMATERA BARAT
}

\author{
Denny Helard, Shinta Indah, Nurul Fitria \\ Jurusan Teknik Lingkungan, Fakultas Teknik, Universitas Andalas \\ Kampus Limau Manis, UNAND Padang 25163, Indonesia \\ E-mail: dennyhelard@ft.unand.ac.id
}

\begin{abstract}
ABSTRAK
Penelitian ini bertujuan untuk memperoleh gambaran yang lebih lengkap tentang konsentrasi sulfat dan parameter lingkungan (debit, Q; pH, temperatur, T; dissolved oxygen, DO; dan daya hantar listrik, DHL) di Sungai Batang Arau, Padang. Selain menyajikan profil konsentrasi dan membandingkannya dengan baku mutu pada Peraturan Gubernur Sumatera Barat No. 5 Tahun 2008, analisis korelasi antar parameter dan variasi spasial konsentrasi sulfat di sepanjang sungai juga dilakukan. Hasil analisis menunjukkan konsentrasi sulfat cenderung meningkat dari hulu ke hilir sungai begitu juga dengan parameter lingkungan. Nilai konsentrasi sulfat secara rata-rata berada pada rentang 25,9-115,1 mg/L dan berada di bawah baku mutu (400 mg/L). Analisis korelasi Rank Spearman menunjukkan bahwa parameter sulfat berkorelasi cukup kuat dan signifikan dengan $Q$ $(r=0,581, p=0,000), T(r=0,448, p=0,008)$, dan $D H L(r=0,411, p=0,008)$ dan tidak berkorelasi dengan pH $(r=-0,194, p=0,231)$ dan DO $(r=-0,279, p=0,081)$. Analisis spasial dengan one-way ANOVA pada tingkat kepercayaan 95\% menunjukkan perbedaan lokasi sampling tidak mengakibatkan perbedaan konsentrasi sulfat yang signifikan (p>0,05), kecuali antara titik S1 dengan S7 dan S8. Lebih lanjut, analisis spasial dengan menggunakan analisis klaster mengelompokkan titik sampling ke dalam dua klaster, yaitu klaster 1 yang terdiri dari titik S1 sampai titik S7 dan klaster 2 (S8) yang menggambarkan perubahan konsentrasi pencemar sulfat dari konsentrasi rendah ke konsentrasi sedang.
\end{abstract}

Kata kunci: Batang Arau, sulfat, analisis korelasi, analisis variasi spasial

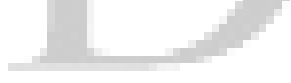

\section{ABSTRACT}

This study aimed to obtain a more comprehensive analysis of sulfate concentration of in Sungai Batang Arau, Padang. In addition to concentration profile of sulfate, correlation analysis between sulfate and environmental parameters (flowrate-Q, temperature- $T, p H, D O$ and electrical Conductivity-EC) and spatial variation analysis of sulfate along the river were also performed. The analysis showed sulfate concentration tended to increase from upstream to downstream. Sulfate concentrations ranged from 25.9 to $115.1 \mathrm{mg} / \mathrm{L}$ and were below the quality standard $(400 \mathrm{mg} / \mathrm{L})$. Spearman Rank Correlation analysis showed a relative strong correlation of sulfate and significant with $Q(r=0.581, p=0.000), T(r=0.448, p=0.008)$, and DHL $(r=0.411, p=0.008)$ and no correlation with $\mathrm{pH}(r=-0.194, p=0.231)$ and DO $(r=-0.279, p=0.081)$. Result of spatial analysis with a one-way ANOVA at 95\% confidence level indicated that there was no a significant variability of sulfate concentration at the sampling stations ( $p>0.05$ ) except for S1 with S7 and S8. Moreover, cluster analysis grouped 8 sampling stations into two clusters, low and moderate polluted, based on similarities of sulfate characteristics.

Keywords: Batang Arau, sulfate, correlation analysis, spatial variation analysis 


\section{PENDAHULUAN}

Bapedalda Padang melaporkan kondisi air Sungai Batang Arau setiap tahun semakin tinggi tingkat pencemarannya, dimana peruntukannya sudah masuk golongan kelas II. Dari lima sungai yang diteliti kualitas airnya oleh Bapedalda diantaranya Batang Kandis, Batang Kuranji, Air Dingin, Batang Arau dan Timbalun, Sungai Batang Arau dinyatakan sebagai sungai yang paling tercemar. Sungai Batang Arau merupakan salah satu sungai terbesar yang terdapat di Sumatera Barat yang dimanfaatkan masyarakat untuk kegiatan pengairan sawah, Mandi Cuci Kakus (MCK), penggalian pasir, serta sebagai badan air penerima air buangan domestik dan industri. Penyebab tingginya tingkat pencemaran adalah karena banyaknya industri yang berdiri di lokasi itu, di antaranya limbah PT Semen Padang, pabrik karet, bengkel-bengkel serta sampah domestik dan komersil (Bapedalda Kota Padang, 2013).

Di antara bahan pencemar yang masuk dari aktivitas tersebut adalah senyawa kimia yang pada konsentrasi tertentu bersifat toksik adalah sulfat $\left(\mathrm{SO}_{4}{ }^{2-}\right)$. Hasil penelitian Maharani (2006) tentang kualitas air Sungai Batang Arau pada musim hujan menunjukkan konsentrasi sulfat berkisar 2,390 $\mathrm{mg} / \mathrm{l}-36,470 \mathrm{mg} / \mathrm{l}$. Sementara itu, hasil penelitian Defi (2006) tentang kualitas air Sungai Batang Arau pada musim kemarau menunjukkan konsentrasi sulfat berkisar 16,650 mg/l - 38,840 mg/l. Baku mutu parameter sulfat berdasarkan Peraturan Pemerintah (PP) RI nomor 82 tahun 2001 tentang pengelolaan Kualitas Air dan Pengendalian Pencemaran Air untuk kelas I adalah sebesar $400 \mathrm{mg} / \mathrm{l}$ sehingga pada penelitian tersebut kandungan sulfat di Sungai Batang Arau masih di bawah baku mutu.

Berdasarkan hasil analisis laboratorium Bapedalda Kota Padang tahun 2012, dengan pengukuran yang dilakukan dari titik Lubuk Paraku sampai dengan titik Muaro (Jembatan Siti Nurbaya) konsentrasi sulfat yang didapatkan berkisar antara 3,201 mg/L - 33,200 mg/L. Angka tersebut menunjukan konsentrasi sulfat di Sungai Batang Arau masih berada di bawah baku mutu Peraturan Gubernur Sumatera Barat nomor 5 tahun
2008 tentang penetapan Kriteria Mutu Air Sungai di Propinsi Sumatera Barat yang sama nilainya dengan Peraturan Pemerintah Republik Indonesia No. 82 Tahun 2001 yaitu sebesar $400 \mathrm{mg} / \mathrm{L}$ untuk air kelas I. Sementara itu, hasil analisis laboratorium Bapedalda Kota Padang tahun 2013 konsentrasi sulfat yang didapatkan berkisar antara 4,250 mg/L - 188,500 mg/L. Angka tersebut menunjukan konsentrasi sulfat Sungai Batang Arau masih berada di bawah baku mutu.

Sejauh ini upaya pemantauan kualitas air Sungai Batang Arau yang telah dilakukan hanya memaparkan profil konsentrasi yang kemudian dibandingkan dengan baku mutu tanpa analisis lebih lanjut seperti kolerasi antar parameter dan analisis variasi spasial (lokasi sampling) di sungai tersebut. Hal ini didasari karena setiap lokasi mempunyai tata guna lahan serta aktivitas manusia dan sumber pencemar yang berbeda sehingga akan menghasilkan debit dan konsentrasi pencemar yang berbeda pula.

Penelitian ini bertujuan untuk menganalisis konsentrasi sulfat di Sungai Batang Arau meliputi analisis deskriptif untuk profil konsentrasi, analisis korelasi antar parameter dan analisis variasi spasial. Analisis kolerasi memberikan gambaran seberapa kuat hubungan antar sesama parameter pencemar dan parameter lingkungan. Sementara itu analisis variasi spasial memberikan informasi tentang seberapa signifikan perbedaan konsentrasi pencemar pada titik sampling yang berbeda. Hal ini dapat menjadi acuan untuk meneliti lebih lanjut penyebab dari perbedaan tersebut ditinjau dari faktor-faktor yang mempengaruhi seperti sumber pencemar, aktivitas di sekitar lokasi dan juga tata guna lahan di titik sampling tersebut. Dari hasil kedua analisis ini akan memberikan gambaran yang lebih lengkap mengenai konsentrasi sulfat sehingga dapat menjadi acuan dalam upaya pemantauan kualitas dan pengendalian pencemaran Sungai Batang Arau untuk selanjutnya. 


\section{METODOLOGI}

\section{Penentuan Lokasi dan Titik Sampling}

Pemilihan lokasi pengambilan sampel dilakukan berdasarkan SNI 03-7016-2004 tentang tata cara pengambilan contoh dalam rangka pemantauan kualitas air pada suatu daerah pengaliran sungai dengan mempertimbangkan pengaruh dari kegiatan yang ada di sekitar Sungai Batang Arau yaitu buangan domestik, buangan industri, buangan kawasan komersial, dan buangan pertanian (BSN, 2004). Pengambilan sampel dilakukan secara duplo di setiap titik sampling pada bulan Januari sampai dengan Mei 2014. Selain itu juga mengacu pada SNI 6989-57-2008 tentang metoda pengambilan contoh air permukaan yaitu pada sumber air alamiah/referensi (Base line station), sumber air tercemar (Impact Station), dan sumber pencemar. Peta persebaran titik sampling dapat dilihat pada Gambar 1 sementara uraian mengenai lokasi titik sampling dapat dilihat pada Tabel 1.

\section{Studi Pendahuluan}

Studi pendahuluan dilakukan untuk menentukan kondisi awal kualitas air Sungai Batang Arau berupa temperatur, $\mathrm{pH}$, dan DO sesuai dengan SNI 03-7016-2004. Menurut SNI ini, studi pendahuluan di sungai dapat dilakukan dengan frekuensi pengambilan contoh setiap hari selama 7 hari berturutturut atau setiap empat jam selama 7 hari berturut-turut. Frekuensi pengambilan contoh seperti tersebut di atas masih dapat berubah disesuaikan fasilitas yang ada. Oleh karena itu, pengukuran dilaksanakan selama 7 hari, yaitu setiap 4 jam selama 1 hari pertama, lalu pada 6 hari berikutnya pengukuran dilaksanakan pada saat konsentrasi DO terburuk yang didapat pada hari pertama yaitu pukul 12.00-16.00.

\section{Pengambilan Sampel}

Berdasarkan SNI 03-7016-2004 tentang tata cara pengambilan contoh dalam rangka pemantauan kualitas air pada suatu daerah pengaliran sungai frekuensi pengambilan sampel pada air sungai dapat dilakukan setiap 2 minggu. Karena kualitas air sungai umumnya hanya berubah karena pengaruh curah hujan, sehingga perubahan tersebut bersifat bulanan atau musiman, maka pengambilan sampel dilakukan setiap 2 minggu selama 5 kali. Berdasarkan SNI 6989-57-2008 tentang Metoda Pengambilan Contoh Air Permukaan, pengambilan sampel untuk studi kualitas air sungai dilakukan pada beberapa titik, yaitu: a.) Sumber air alamiah, yaitu pada lokasi yang belum atau sedikit terjadi pencemaran; b.) Sumber air tercemar, yaitu pada lokasi yang telah menerima limbah; dan c.) Sumber air yang dimanfaatkan.

Dari hasil penelitian pendahuluan diperoleh data bahwa titik sampling S1 dan S2 memiliki debit dibawah $5 \mathrm{~m}^{3} /$ detik sehingga pengambilan sampel hanya dilakukan pada satu titik yakni di bagian tengah sungai pada setengah kedalaman sungai sementara titik sampling lainnya (S3-S8) memiliki debit besar dari $5 \mathrm{~m}^{3} /$ detik namun masih kecil dari $150 \mathrm{~m}^{3} /$ detik sehingga pengambilan sampel dilakukan di bagian kiri dan kanan sungai pada setengah kedalaman sungai kemudian dicampur.

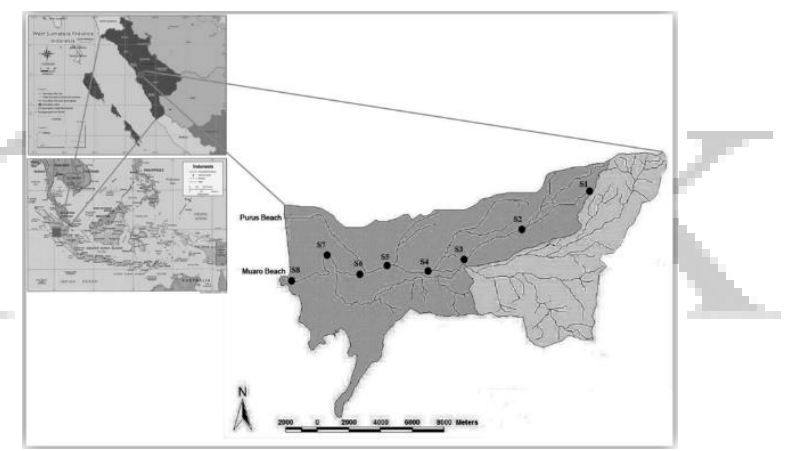

Gambar 1. Titik Pengambilan Sampel

\section{Analisis Sampel Air di Laboratorium}

Sampel air dianalisis di Laboratorium Lingkungan, Jurusan Teknik Lingkungan, Fakultas Teknik, Universitas Andalas. Analisis terhadap konsentrasi sulfat menggunakan metode Turbidimetri sesuai dengan cara uji sulfat menurut SNI 066989.20-2004.

\section{Pengolahan Data dan Pembahasan}

Pengolahan dan pembahasan data meliputi konsentrasi masing-masing sulfat dan klorida dalam air. Nilai konsentrasi sulfat dan klorida kemudian dibandingkan dengan baku mutu yang telah ditetapkan pada Peraturan Gubernur Nomor 05 Tahun 2008 tentang Pengelolaan Kualitas Air dan Pengendalian Pencemaran Air Sumatera Barat. 
Analisis data yang digunakan dalam penelitian ini adalah: analisis deskriptif, analisis korelasi (metode Rank Spearman) dan analisis variasi spasial (metode one-way ANOVA dengan tingkat signifikasi 0,05 dan analisis klaster). Analisis korelasi Rank Spearman's digunakan untuk menentukan apakah terdapat hubungan yang signifikan antara parameter sulfat dan parameter lingkungan (Plummer and Long, 2007). Secara statistic, signifikansinya diatur pada nilai $p<0.05$. Untuk uji variasi spasial, data parameter kualitas air dinormalisasi dengan transformasi $\log 10$ dan kemudian menjadi subjek untuk Kurskall-Wallis nonparametric one-way ANOVA (Amisah and Nuamah, 2014). Analisis klaster (cluster analysis) digunakan untuk mengidentifikasi sumber dari perubahan kualitas air dan untuk mengelompokkan lokasi sampling ke dalam beberapa zona yang mempunyai kesamaan data (transformasi $\mathrm{z}$ dari data, indeks kesamaan dengan menggunakan jarak Euclidean dan metode Ward's untuk penghubungnya) menggunakan data yang diambil dari sungai Batang Arau (Boyacioglu and Boyacioglu, 2007). Analisis klaster menggunakan metode Ward dianggap sebagai metode yang sangat efisien untuk diterapkan pada data yang telah distandarisasi menurut beberapa penelitian terdahulu (Vega et al., 1998; Simeonov et al., 2003; Helena et al., 2000; Helard et al., 2012). Semua analisis data menggunakan perangkat lunak SPSS ver. 20.

\section{HASIL DAN PEMBAHASAN}

\section{Analisis Deskriptif}

Analisis deskriptif bertujuan untuk memaparkan nilai konsentrasi rata-rata, standar deviasi dan rentang nilai (minimum dan maksimum) dari setiap konsentrasi parameter lingkungan (debit (Q), $\mathrm{pH}$, temperature (T), dissolved oxygen (DO) dan daya hantar listrik (DHL)) dan parameter pencemar (sulfat, $\mathrm{SO}_{4}$ ) seperti yang ditunjukkan pada Tabel 1 dan disajikan dalam bentuk boxplot yang menampilkan nilai maksimum, minimum dan median konsentrasi (Gambar 2a-2f yang menunjukkan variasi nilai debit, $\mathrm{pH}$, temperature, DO, DHL dan $\mathrm{SO}_{4}$ secara berturut-turut).
Tabel 1. Konsentrasi parameter lingkungan dan sulfat pada 8 titik sampling di sungai Batang Arau.

\begin{tabular}{|c|c|c|c|c|c|c|}
\hline Stasiun & $Q, m^{3} / s$ & $\mathrm{pH}$ & $\mathrm{T},{ }^{0} \mathrm{C}$ & $\mathrm{DO}, \mathrm{mg} / \mathrm{L}$ & DHL, umho/cm & $\mathrm{SO}_{4}, \mathrm{mg} / \mathrm{L}$ \\
\hline \multirow[t]{2}{*}{ S1 } & $0.9-1.7 *$ & $8.0-8.9$ & $24.2-26.2$ & $7.9-8.9^{*}$ & $172-206$ & $18.0-35.1$ \\
\hline & $1.3 \pm 0.3 * *$ & $8.3 \pm 0.4$ & $24.9 \pm 0.8$ & $8.2+0.4 * *$ & $189 \pm 17$ & $25.9 \pm 7.0$ \\
\hline \multirow[t]{2}{*}{$\$ 2$} & $2.2-2.8$ & $8.1-9.1$ & $26.4-31.2$ & $6.4-8.3$ & $146-308$ & $30.7-109.7$ \\
\hline & $2.4 \pm 0.3$ & $8.7 \pm 0.4$ & $28.6 \pm 1.8$ & $7.2 \pm 0.7$ & $60 \pm 216$ & $76.3 \pm 35.2$ \\
\hline \multirow[t]{2}{*}{53} & $1.6-3.8$ & $7.8-9.6$ & $28.1-34.7$ & $6.1-8.2$ & $182-234$ & $31.7-88.1$ \\
\hline & $2.9 \pm 0.8$ & $8.7 \pm 0.9$ & $30.7 \pm 2.5$ & $7.4 \pm 0.9$ & $21 \pm 216$ & $60.1 \pm 26.7$ \\
\hline \multirow[t]{2}{*}{54} & $6.4-8.7$ & $7.4-8.5$ & $29.3-33.4$ & $3.3-7.9$ & $182-298$ & $31.2-109.5$ \\
\hline & $7.3 \pm 1.0$ & $7.9 \pm 0.4$ & $30.6 \pm 1.7$ & $6.2 \pm 1.8$ & $249 \pm 43$ & $83.1 \pm 30.5$ \\
\hline \multirow[t]{2}{*}{55} & $3.1-3.8$ & $7.1-8.2$ & $29.2-33.7$ & $5.2-7.9$ & $183-312$ & $29.4-83.6$ \\
\hline & $3.4 \pm 0.3$ & $7.7 \pm 0.5$ & $30.5 \pm 1.8$ & $6.9 \pm 1.1$ & $262 \pm 49$ & $57.2 \pm 22.8$ \\
\hline \multirow[t]{2}{*}{56} & $2.4-4.1$ & $7.2-8.1$ & $29.6-33.6$ & $6.9-7.6$ & $183-559$ & $28.6-58.5$ \\
\hline & $3.3 \pm 0.8$ & $7.6 \pm 0.4$ & $30.5 \pm 1.7$ & $7.2 \pm 0.3$ & $316 \pm 142$ & $48.4 \pm 11.8$ \\
\hline \multirow[t]{2}{*}{57} & $4.0-5.8$ & $7.2-8.2$ & $29.7-32.3$ & $6.6-7.9$ & $369-1910$ & $15.8-124.4$ \\
\hline & 4.9 \pm 0.8 & $7.6 \pm 0.4$ & $30.4 \pm 1.1$ & $7.0 \pm 0.5$ & $1362+594$ & $87.0 \pm 45.0$ \\
\hline \multirow[t]{2}{*}{58} & $4.1-7.3$ & $6.9-8.1$ & $29.5-32.4$ & $5.5-8.0$ & $2018-5097$ & $71.2-128.5$ \\
\hline & $5.6 \pm 1.3$ & $7.5 \pm 0.6$ & $30.4 \pm 1.1$ & $6.7 \pm 0.9$ & $4041 \pm 1212$ & $115.1 \pm 24.8$ \\
\hline
\end{tabular}

Hasil pengukuran debit menunjukkan nilai yang bervariasi dari titik S1 hingga titik S8. Titik terendah berada pada titik S1dan terbesar pada titik S4. Peningkatan debit di lokasi S2 disebabkan bergabungnya aliran Sungai Batang Idas dan Sungai Lubuk Kilangan, sedangkan peningkatan di lokasi A3 yang disebabkan oleh bergabungnya Sungai Rimbo Data dan Sungai Padang Besi (Gambar 2a dan Tabel 1).

Pada Gambar 2b, hasil pengukuran derajat keasaman $(\mathrm{pH})$ menunjukkan bahwa nilai $\mathrm{pH}$ menurun dari daerah hulu ke hilir Sungai Batang Arau. Hal ini menggambarkan bahwa semakin ke hilir, kondisi pH pada aliran Sungai Batang Arau semakin netral. Nilai pH tertinggi terdapat pada lokasi sampling A1 (Lubuk Paraku) yaitu sebesar 8,9 dan nilai terendah berada pada lokasi sampling A8 (Muaro) sebesar 7,5. Berdasarkan baku mutu yang telah ditetapkan pada Peraturan Gubernur Sumatera Barat No.5 tahun 2008 peruntukkan kelas I, nilai $\mathrm{pH}$ di sepanjang Sungai Batang Arau belum melampai batas yang ditetapkan yaitu pada rentang 6-9.

Nilai rata-rata temperatur cenderung meningkat dari hulu ke hilir Sungai Batang Arau (Gambar 2c). Nilai temperatur tertinggi berada pada titik sampling S3 yaitu sebesar $30,7{ }^{\circ} \mathrm{C}$ dan nilai rata-rata temperatur terendah yaitu pada titik sampling S1 sebesar $26,2{ }^{\circ} \mathrm{C}$. Berdasarkan 
Peraturan Gubernur Sumatera Barat No.5 Tahun 2008 baku mutu untuk nilai temperatur adalah deviasi 3 dari peruntukkan air kelas I yaitu sebesar 23,2 $29,2{ }^{\circ} \mathrm{C}$.

Hasil pengamatan nilai DO pada setiap lokasi sampling dapat dilihat pada Gambar 2d. Dapat dilihat pada Tabel 2, nilai ratarata DO berfluktuasi dari hulu ke hilir. Konsentrasi DO terendah berada pada titik $\mathrm{S} 4$ dengan nilai rata-rata $6,2 \mathrm{mg} / \mathrm{L}$, kondisi ini bisa disebabkan karena pada titik S4 terdapat efluen dari beberapa industri yang menyebabkan turunnya nilai DO. Sedangkan konsentrasi DO tertinggi yaitu pada titik A1 dengan nilai $8,2 \mathrm{mg} / \mathrm{l}$, hal ini disebabkan karena di daerah ini masih terlindungi dari aktivitas manusia dan jauh dari pemukiman. Berdasarkan Peraturan Gubernur Sumatera Barat No. 5 Tahun 2008 Tentang Penetapan Kriteria Mutu Air Sungai di Provinsi Sumatera Barat nilai DO Sungai Batang Arau masih berada pada ambang batas baku mutu air kelas II.

Nilai DHL menunjukkan ukuran seberapa kuat suatu larutan dapat menghantarkan listrik (Efendi, 2003). Nilai DHL Sungai Batang Arau dapat dilihat pada Tabel 1 dan Gambar 2e. nilai rata-rata DHL meningkat dari arah hulu ke hilir. Nilai konduktivitas terendah yaitu pada titik $\mathrm{S} 1$ dengan nilai DHL $173 \mu \mathrm{mhos} / \mathrm{cm}$. Hal ini disebabkan karena daerah ini adalah daerah hulu sungai yang merupakan kawasan yang masih alami dimana mineralnya berasal dari pelapukan batuan. Sedangkan nilai DHL tertinggi yaitu pada titik S8 dengan nilai $5097 \mu \mathrm{mhos} / \mathrm{cm}$, dimana pada daerah ini banyak pencemar atau senyawa-senyawa lain dalam bentuk ion sehingga akan meningkatkan kemampuan air untuk menghantarkan listrik. Selain itu titik S8 sangat dekat dengan laut sehingga potensi terjadinya intrusi air laut cukup besar.
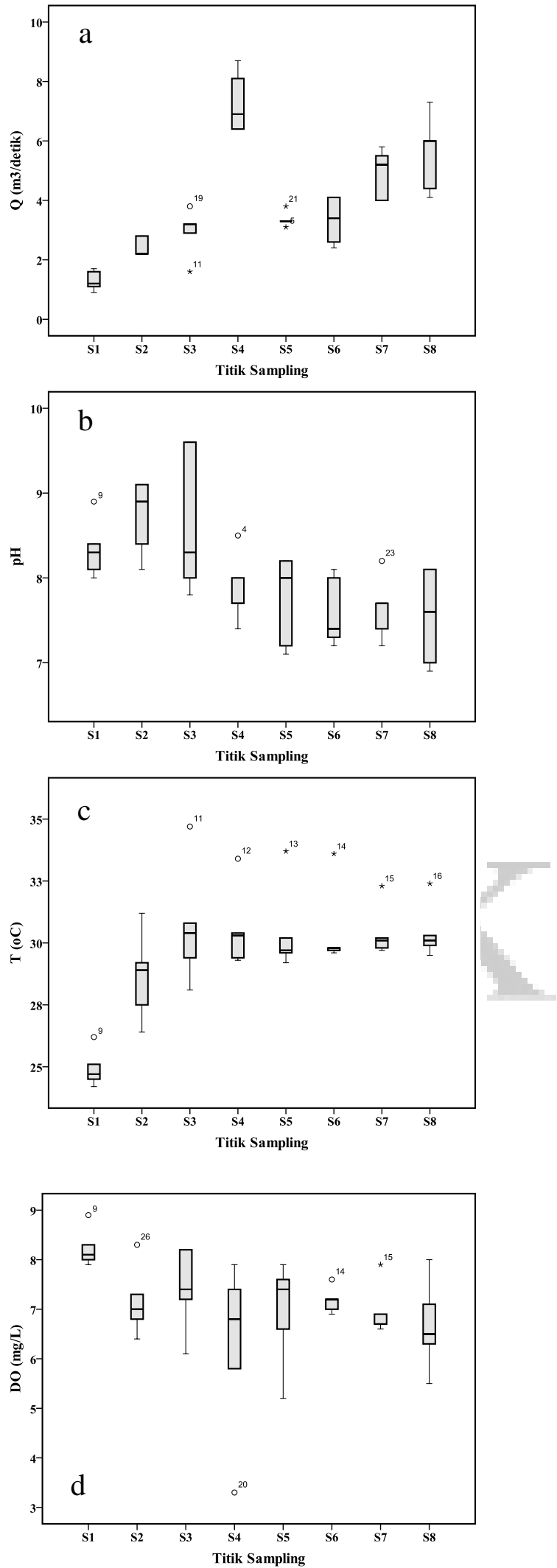

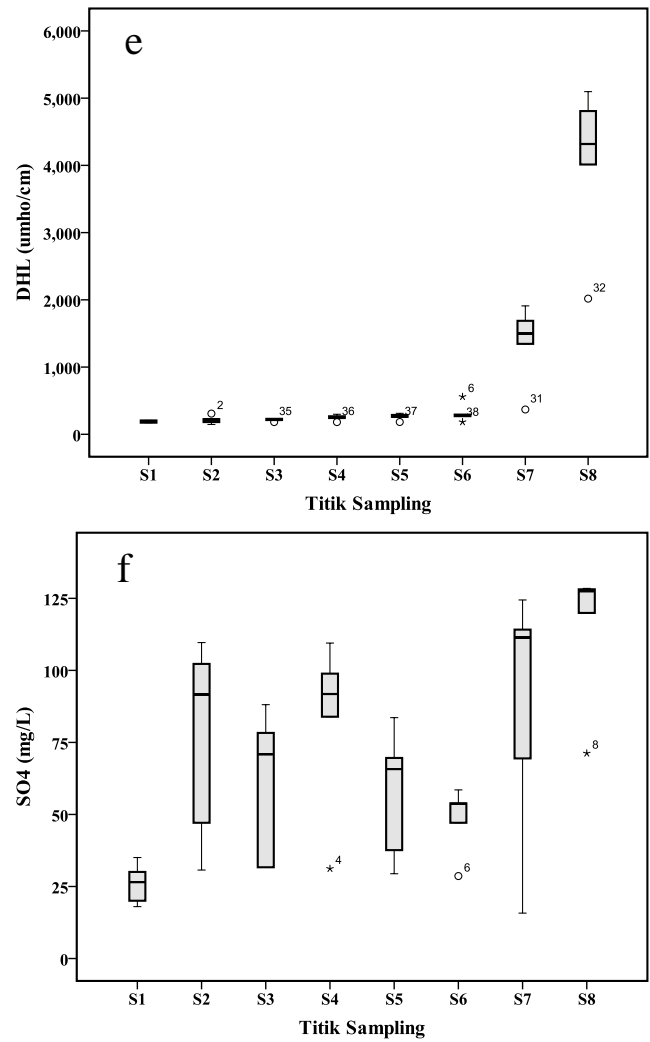

Gambar 2. Grafik Boxplot dari: a). Q; b). pH; c). T; d). DO; e). DHL; dan f). $\mathrm{SO}_{4}$

Gambar 2f menunjukkan bahwa sebaran data dan rata-rata konsentrasi sulfat di setiap titik belum melampaui baku mutu. Menurut Peraturan Gubernur Sumatera Barat No.5 tahun 2008, nilai maksimum yang diperbolehkan untuk air kelas I adalah sebesar $400 \mathrm{mg} / \mathrm{L}$. Titik S2 memiliki kotak yang lebih panjang dibandingkan titik lainnya. Hal ini menggambarkan bahwa 50\% data pada titik S2 sebarannya lebih bervariasi, begitu juga dengan titik S3, S5 dan S7.

\section{Analisis Korelasi}

Koefisien korelasi menunjukkan hubungan antara dua variabel. Besarnya koefisien korelasi (r) berkisar antara -1 sampai dengan +1. Dari Tabel 2 dapat dilihat bahwa korelasi $\mathrm{SO}_{4}$ dengan beberapa parameter lainnya cukup lemah, positif namun sangat signifikan. Hubungan korelasi yang lemah, positif namun sangat signifikan tersebut ditunjukkan antara $\mathrm{SO}_{4}$ dengan $\mathrm{Q}, \mathrm{T}$ dan DHL dengan nilai $r=0,581,0,416$ dan 0,411 dan nilai signifikansi $0,000,0,008$ dan 0,008 secara berturut-turut. Hal ini menunjukkan bahwa kenaikan Q, T dan DHL berpotensi akan diikuti oleh kenaikan konsentrasi $\mathrm{SO}_{4}$.

Tabel 2. Nilai korelasi antar parameter

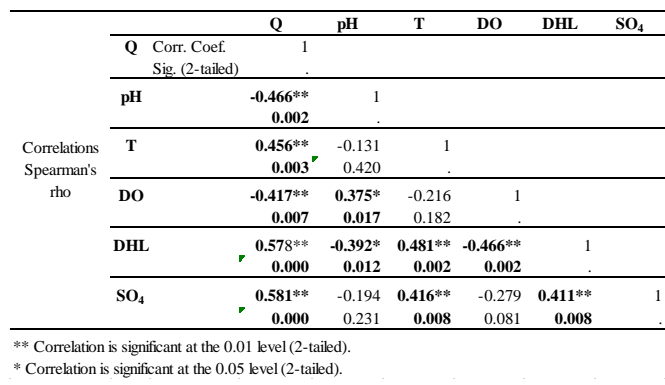

Analisis Variasi Spasial

Nilai signifikansi konsentrasi $\mathrm{SO}_{4}$ terhadap lokasi sampling dapat dilihat pada Tabel 3. Dari tabel tersebut dapat dilihat bahwa secara umum perbedaan lokasi sampling tidak mengakibatkan perbedaan konsentrasi sulfat secara signifikan $(p>0,05)$. Perbedaan yang signifikan hanya terdapat antara titik S1 (base line station) dengan titik S7 dan S8 (impact station).

Nilai signifikansi parameter sulfat pada Tabel 3 menunjukkan angka $p>0,05$ terhadap perubahan konsentrasi sulfat dari titik S1, S2, S3, S4, S5 dan S6 yang berarti tidak terdapat perbedaan konsentrasi sulfat yang signifikan antara titik $\mathrm{S} 1$ terhadap konsentrasi sulfat di titik S2, S3, S4, S5 dan S6.

Pada titik sampling S7 dan S8, aliran sungai Batang Arau menjadi badan air penerima bagi kawasan padat penduduk di kawasan Seberang Padang, Sawahan, dan Alang Laweh dan Parak Rumbio. Selain itu terdapat aliran dari Jati Drain yang melintas dari kawasan Jati, Tarandam, Camar Aur Duri, dan Seberang Padang yang membawa air buangan komersial pertokoan dan pasar. Air sungai Batang Arau di kawasan ini tergolong tercemar ditandai dengan kondisi air yang kumuh, terdapat banyak sampah, endapan di sisi kiri dan kanan sungai, serta tumbuhnya eceng gondok. Nilai signifikansi dari analisis variasi spasial pada Tabel 3 untuk konsentrasi sulfat antara titik S8 dan S7 terhadap titik S2, S3, S4, S5, dan S6 menunjukkan nilai $p>0,05$ yang berarti tidak terdapat perbedaaan yang signifikan. Namun terhadap titik S1, titik S7 memperlihatkan perbedaaan yang signifikan $(p=0,029)$ dan sangat signifikan $(p=0.000)$ dengan titik S8. Perubahan tataguna lahan 
dan berbagai aktivitas manusia sepanjang sungai Batang Arau memberikan berpengaruh terhadap perubahan nilai sulfat antara daerah hulu (S1, base station) dan hilir (S7 dan S8, impact station).

Tabel 3. Signifikansi Parameter Sulfat terhadap Titik Sampling

\begin{tabular}{c|rrrrrrrr}
\hline Tukey HSD & \multicolumn{1}{c|}{ S1 } & S2 & S3 & S4 & S5 & S6 & S7 & S8 \\
\hline S1 & - & & & & & & & \\
\hline S2 & 0.117 & - & & & & & \\
\hline S3 & 0.537 & 0.982 & - & & & & \\
\hline S4 & 0.050 & 1.000 & 0.893 & - & & & \\
\hline S5 & 0.643 & 0.956 & 1.000 & 0.820 & - & & \\
\hline S6 & 0.903 & 0.757 & 0.997 & 0.519 & 1.000 & - & \\
\hline S7 & $\mathbf{0 . 0 2 9}$ & 0.998 & 0.789 & 1.000 & 0.020 & 0.3829 & - \\
\hline S8 & $\mathbf{0 . 0 0 0}$ & 0.380 & 0.067 & 0.616 & $\mathbf{0 . 0 0 0}$ & 0.0133 & 0.754 & \\
\hline
\end{tabular}

Untuk menganalisis variasi spasial lebih lanjut, analisis klaster (cluster analysis) diaplikasikan untuk mendeteksi kesamaan kelompok/klaster antara lokasi pengambilan sampel. Seluruh data sampling dianalisis (setelah data diskalakan dengan transformasi-z) dengan metode penghubung Ward dengan jarak kuadrat Euclidean sebagai ukuran kesamaan (Simeonov et al., 2003).

Dendrogram yang dihasilkan dari analisis klaster (Gambar 3) menunjukkan bahwa delapan titik sampling pada sungai Batang Arau dapat dikelompokkan menjadi dua kelompok klaster secara statistik berbeda signifikan. Klaster 1 terdiri dari titik sampling S1 sampai dengan S7 dan klaster 2 terdiri dari titik S8. Klasifikasi klaster berubah dengan tingkat signifikansi yang berbeda karena titik sampling pada kelompok klaster tersebut memiliki ciri-ciri serupa yang dipengaruhi oleh sumber pencemar yang sama. Bila dibandingkan data parameter yang diuji, dapat disimpulkan bahwa klaster 1 dan 2 berhubungan dengan daerah yang tercemar dengan konsentrasi rendah sampai konsentrasi sedang (moderat).

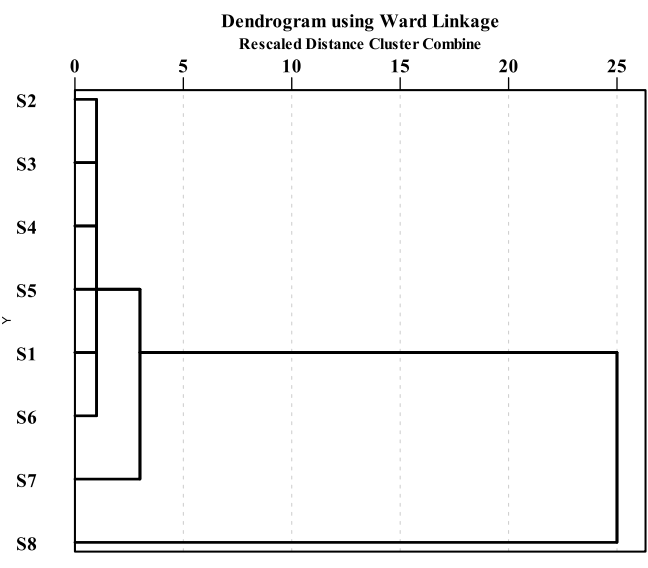

Gambar 3. Dendogram dari Analisis Klaster

\section{SIMPULAN}

Analisis deskirptif menunjukkan bahwa konsentrasi sulfat pada bulan Januari sampai Mei 2014 di sungai Batang Arau secara ratarata berada dalam rentang 25,9-115,1 $\mathrm{mg} / \mathrm{L}$. Berdasarkan Peraturan Gubernur Sumatera Barat Nomor 5 Tahun 2008 tentang Penetapan Kriteria Mutu Air Sungai di Provinsi Sumatera Barat maka nilai konsentrasi ini masih berada di bawah baku mutu yang disyaratkan (maksimum 400 $\mathrm{mg} / \mathrm{L}$ untuk air kelas I);

Analisis korelasi menunjukkan hubungan yang lemah, positif namun sangat signifikan antara parameter sulfat dengan $\mathrm{Q}(\mathrm{r}=0,581$; $p=0,000), \quad \mathrm{T}(\mathrm{r}=0,416 ; p=0,008)$ dan DHL $(\mathrm{r}=0,411 ; p=0,008)$. Nilai korelasi dan signifikansi ini memberikan gambaran bahwa kenaikan nilai $\mathrm{Q}, \mathrm{T}$ dan DHL akan berpotensi menggambarkan kenaikan konsentrasi sulfat juga.

Analisis variasi spasial dengan One-way ANOVA menyimpulkan bahwa perbedaan lokasi titik sampling tidak memberikan perbedaan konsentrasi sulfat yang signifikan antara titik S1 (baseline station) dengan titik S2, S3, S4, S5 dan S6 (impact station) namun berbeda signifikan dengan titik S7 dan S8. Dengan demikian, untuk penelitian berikutnya terhadap parameter sulfat ini, jumlah lokasi sampling dapat direduksi menjadi tiga lokasi sampling yaitu S1 (baseline station) dan S7 serta S8 sebagai impact station.Lebih lanjut, dengan menggunakan analisis klaster, delapan titik sampling pada sungai Batang Arau dapat dikelompokkan menjadi dua kelompok 
klaster yang secara statistik berbeda secara signifikan.

\section{UCAPAN TERIMA KASIH}

Ucapan terima kasih penulis sampaikan kepada DIPA Universitas Andalas atas bantuan dana untuk penelitian ini, sesuai dengan Surat Perjanjian Pelaksanaan Penugasan Penelitian Hibah Bersaing BATCH I tahun anggaran 2015 No. 50/H.16/HB/LPPM/2015, tanggal 9 Februari 2015.

\section{DAFTAR PUSTAKA}

Amisah, S. and Nuamah, P.A (2014). Spatial and Temporal Variations in Microbiological Water Quality of the River Wiwi in Kumasi, Ghana. Water Qual Expo Health, 6: 217-224.

Badan Standarisasi Nasional (1991). SNI.062412-1991. Metode Pengambilan Contoh Kualitas Air.

Badan Standarisasi Nasional (2008). SNI.6989.58-2008. Metode

Pengambilan Contoh Air Tanah.

Boyacioglu, H. and Boyacioglu, H. (2007). Surface water quality assessment by environmetric methods. Environ Monit Assess, 131: 371-376.

BPS Padang (2013). Padang Utara Dalam Angka Tahun 2013. Padang: Badan Pusat Statistik Kecamatan Padang Utara.
Effendi, H. (2003). Telaah Kualitas Air. Jakarta: Penerbit Kanisius.

Helard, D., Fajri, J.A., Setiyawan, A.S., Li, F., Yamada, T., Horio, A., Huang, M. and Kawaguchi, T. (2012). Formation and role of bacterial community in the sediment bed of open channel receiving Johkasou effluent: Multivariate statistical analysis interpretation. Journal of Japan Society of Civil Engineers, Ser. G (Environmental Research), 68 (7): III_1-III_11.

Helena, B., Pardo, R., Vega, M., Barrado, E., Fernandez, J.M. and Fernandez, L. (2000). Temporal evolution of groundwater composition in an alluvial aquifer (Pisuerga River, Spain) by principal component analysis. Water Res., 34: 807-816.

Peraturan Gubernur Sumatera Barat Nomor 5 Tahun 2008 Tentang Penetapan Kriteria Mutu Air Sungai di Provinsi Sumatera Barat.

Simeonov, V., Stratis, J.A., Samara, C., Zachariadis, G., Voutsa, D., Anthemidis, A., Sofoniou, M. and Kouimtzis, Th. (2003). Assessment of the surface water quality in Northern Greece. Water Res., 37: 4119-4124.

Vega, M., Pardo, R., Barrado, E. and Deban, L. (1998). Assesment of seasonal and polluting effects on the quality of river water by exploratory data analysis, Water Res., 32: 35813592. 